\title{
Media Literacy: uma experiência brasileira ${ }^{1}$
}

\author{
Lilian C. Santos ${ }^{2}$ \\ Fabio N. Akhras ${ }^{3}$
}

\begin{abstract}
Resumo: O presente trabalho teve como objetivo a formulação e aplicação de um curso de Media Literacy - Alfabetização em Mídias, que levasse em conta o contexto sócioeconômico e psicossocial das crianças brasileiras. Esse curso, num primeiro momento, visa a desconstrução dos conteúdos midiáticos presentes na vida dos alunos. Essa desconstrução se dá pela verificação do emissor, da mensagem e do receptor, da análise da linguagem cinematográfica e televisiva, e dos mecanismos da publicidade. Dividimos o curso em análise de linguagem e discussão de conteúdos que sejam relevantes para a formação social das crianças, bem como para o aumento de seu repertório audiovisual.
\end{abstract}

Palavras-chave: media literacy, alfabetização em mídias, linguagem de cinema, linguagem de televisão, propaganda.

Abstract: The objective of this work has been the development and application of a course on media literacy, taking into consideration the socioeconomic and sociopsychological context of the brazilian children. The first aim of this course is the deconstruction of the media contents present in the children's daily life. This deconstruction occurs through the identification of the sender, the message and the receptor, and the analysis of the cinematographic and television language as well as the mechanisms of advertising. We have divided the course into the analysis of language and the discussion of contents that are relevant for the social formation of the children and for the growing of their audiovisual repertoire.

Key words: media literacy, cinema language, television language, advertising. 
Estando numa condição em que a publicidade encontra múltiplas formas de influência numa sociedade em que o consumismo é cada vez mais incentivado, a mídia está cada vez mais presente em nosso cotidiano, e das mais diversas formas: da propaganda na televisão no intervalo do desenho animado até o merchandising da novela, na revista em quadrinhos e no cinema, estamos lidando com um número cada vez maior de informação em diversos tipos de mídia.

O Brasil, sendo um país em desenvolvimento, já conta com um enorme número de produtos midiáticos à disposição de toda a população (Bortoletto, 2008). Da mesma maneira que ocorre nos países desenvolvidos, todos somos bombardeados por informações audiovisuais em nosso dia a dia. Entretanto, diferentemente, por exemplo, do Reino Unido, não há uma responsabilização por parte do sistema educacional em discutir com as crianças esse conteúdo, de maneira a incentivar a reflexão sobre o consumo e a construção de realidades pelas mídias. Televisão, cinema e internet povoam o cotidiano destas crianças, que absorvem esse conteúdo sem nenhum tipo de acompanhamento didático.

As crianças brasileiras são colocadas à disposição de mídias que, quando interessantes a seu desenvolvimento cognitivo, não contam, muitas vezes, com a continuação de seu trabalho por parte da escola e da família. Quando, por outro lado, são impróprios para suas idades, são assistidos sem a preparação necessária, e sem a discussão que deveria segui-la. Por que uma criança se interessa mais por um vídeo do que pelo outro? O que ela aprende, passando tantas horas de seu dia em frente à televisão, ao computador, ao videogame conectado à rede? Como ela deve aproveitar esse rico material em prol de seu desenvolvimento físico, mental, psíquico e material?

Além de discutir a influência da publicidade, não podemos esquecer os bons frutos que gera o enriquecimento do repertório das crianças no que concerne à linguagem audiovisual usada em outros países, em material audiovisual de 
alcance restrito aos festivais de animação e de cinema. Este material trazido à sala de aula proporciona um enorme crescimento no desenvolvimento geral da criança. Se essa exibição for seguida de uma discussão ativa e atenta, os resultados são mais impressionantes ainda.

Munidas de uma condição mais eficaz no que diz respeito à interpretação dos discursos à sua volta, as crianças podem pensar melhor por si mesmas e concluir com maior autonomia suas opiniões e necessidades. Esse é o objetivo maior do nosso projeto, a construção da autonomia discursiva e de análise dos nossos alunos, no tocante à construção da identidade como cidadão e consumidor.

Este trabalho se baseia, principalmente, na proposta norte-americana do Center for Media Literacy (Jolls, Share \& Thoman, 2001; Jolls \& Thoman, 2007), e do Charter for Media Literacy, do Reino Unido (Wiliam, 2000). A ideia é adaptar a proposta da Alfabetização em Mídias (Media Literacy) para o público brasileiro, considerando as especificidades de mídia de massa e de condições sociais do nosso país.

Dentre outros tópicos, a linguagem de cada mídia é uma constante em nossas aulas, por meio da análise da estrutura narrativa, da montagem cinematográfica, da apresentação dos personagens (Howard \& Mabley, 2005; Campos, 2007; Martin \& Granja, 2007), e da composição e escolha de cores em produtos impressos (Peirce, 2003). Além disso, a consciência dos processos pelos quais a publicidade, a propaganda e os meios de comunicação se desenvolveram dão ferramentas à análise posterior destes produtos por parte dos alunos (Mattelart, 2004).

Assim, a importância do nosso projeto repousa no fato de que não há no Brasil nenhum curso de Media Literacy abrangendo a sua desconstrução, e adaptado à realidade de nosso país. De nada adiantaria apenas aplicarmos os cursos desenvolvidos em outros países, uma vez que para obtermos sucesso 
devemos realizar pesquisa sobre qual tipo de mídia é a mais influente em um determinado grupo de crianças e por quê, trabalhando com a linguagem dos produtos mais significativos no cotidiano dessas crianças.

Desta maneira, nosso curso foi aplicado com crianças de dois contextos sociais diferentes. Primeiramente, foi realizada uma oficina de 16 horas para crianças pertencentes à comunidade da Floresta Nacional de Caxiuanã, no Pará, fazendo parte da II Olimpíada de Ciências na Floresta, realizada pelo Museu Paraense Emilio Goeldi. Posteriormente, um curso de 30 horas foi aplicado nas dependências do CTI - Centro de Tecnologia e Informação Renato Archer, em Campinas (SP), para crianças provenientes de populações de baixa renda da periferia de Campinas.

O curso busca desenvolver nos alunos um olhar crítico sobre os principais produtos audiovisuais que os cercam: desenhos animados, comerciais veiculados na televisão aberta e a cabo, comerciais impressos em revistas, filmes, animações e novelas. O foco está na discussão dos principais meios de criação de realidades e da sensação de necessidades e regras sociais, por meio da estrutura narrativa, da montagem cinematográfica, da apresentação dos personagens, e da composição e escolha de cores em produtos impressos. Os objetivos do curso, são, em resumo, os seguintes:

- Identificação, em todos os meios, de um emissor, um receptor específico, e uma mensagem que pode ser clara ou subentendida.

- Introdução à linguagem cinematográfica: estudo da apresentação de metáforas e símbolos imagéticos, montagem, apresentação de personagens, trilha sonora e suas implicações sensoriais, diálogos, e estrutura narrativa.

- Discussão dos assuntos tratados nos vídeos apresentados e relativização de seus universos, como forma de verificar e analisar as realidades, necessidades e comportamentos incentivados por meio das narrativas. 
- Introdução de um repertório audiovisual diverso. Apresentação também de vídeos não veiculados para o grande público, como forma de apresentar aos alunos um universo audiovisual pouco conhecido e bastante interessante para abrir novas perspectivas no âmbito das possibilidades midiáticas.

Nas próximas seções é discutida a forma como esses objetivos são alcançados através da estrutura criada para o curso. No curso, cada aula consiste da exposição diversificada de produtos audiovisuais, atrelada a atividades que visem estimular a desconstrução de sua linguagem e ideias subtextuais. O objetivo maior é estimular a análise crítica da mídia pelos alunos, que serão capazes de discutir todo o texto em áudio, vídeo e imagens em geral que os cercam em seu dia a dia.

\section{A questão do emissor, do receptor e da mensagem}

Todo produto midiático é feito por alguém (e é necessário para a discussão que se identifique esse interlocutor), para um público específico (e essa especificidade caracteriza a linguagem a ser utilizada) e tem uma mensagem, uma ideia que pode ser mais clara (como nos desenhos animados - que não raro passam conteúdos comportamentais ou de cidadania -, ou nas propagandas governamentais - que visam promover um comportamento nos indivíduos daquele território) ou mais obscura (um filme, uma novela, as ficções em geral, em que, dentro de uma ideia de ficcionalização, numerosos valores e opiniões são posicionadas). O primeiro passo para uma análise mais segura dos produtos audiovisuais é a identificação desses três fatores.

Desta maneira, iniciamos o curso com um compilado de vídeos das mais diversas origens, e discutimos seus universos. Passamos um vídeo governamental (campanha do governo espanhol para conscientização sobre a postagem de imagens pessoais na internet), um desenho do Pato Donald que discute os maus 
e bons comportamentos tidos por uma criança (anjinho manda acordar cedo e ir para a escola e diabinho manda dormir até tarde e fumar), o merchandising da Tucson na novela das oito (elogios ao carro inseridos na trama da novela), e cenas do filme $A$ mulher invisível (a "mulher perfeita" é branca, loira, magra, nua, ajoelhada limpando os móveis). Discutimos com as crianças o que esses vídeos têm em comum, e tentamos identificar os três fatores da comunicação: o emissor, o receptor e a mensagem e seu universo.

Como atividade para as crianças, passamos o filme Neighbours, de Norman McLaren, e pedimos para eles escreverem o que acontece, depois discutimos o que é fato e o que é dedução, e ressaltamos que cada pessoa tem uma forma diferente de ver a mesma história. Ou seja, essa mensagem não é clara e depende da interpretação do receptor.

Neste filme de 1952, Norman McLaren, um dos pioneiros da animação mundial, conta a história de dois vizinhos que são muito parecidos, se dão muito bem, até que surge uma flor entre os terrenos das duas casas, o que causa uma briga de proporções gigantescas no decorrer da trama. Quando perguntadas sobre o que aconteceu no filme, as crianças ressaltam primeiramente fatos concretos, como o fato de eles estarem sentados na frente de suas casas, por exemplo. Alguns ancoram acontecimentos que, por mais que não façam parte do acontecimento principal, chamaram a sua atenção, como o fato de um bater na mulher e nos filhos do outro. Entretanto, a maioria concordou em desaprovar a atitude dos personagens, uns porque acreditam que uma flor não é motivo para tanta guerra, outros porque se escandalizam com o estrago causado. A figura 1 mostra algumas respostas dos alunos. 

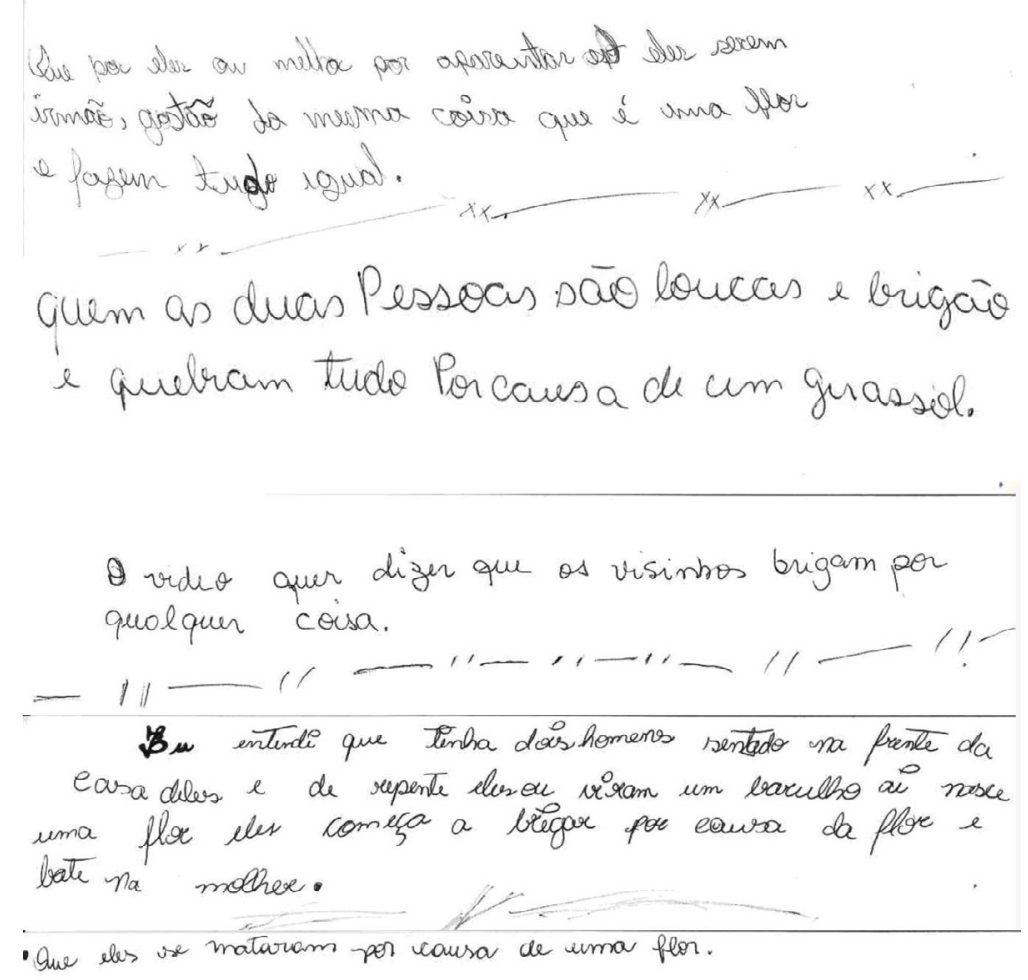

Fig. 1 - Interpretação inicial dos alunos sobre o vídeo Neighbours

\section{A propaganda}

Ainda na questão do universo intrínseco dos vídeos, nos aprofundamos um pouco mais na questão da propaganda discutindo duas propagandas brasileiras: uma de sandálias (a propaganda das sandálias havaianas, com a vovó dizendo que deseja que a neta encontre um bom homem para o sexo), que, apesar de não apresentar nudez nem palavras obscenas, foi censurada; e outra de cerveja (a propaganda da cerveja com a Juliana Paes, em que a mulher é estimulada pelos homens à sua volta a rasgar a saia para conseguir consumir o produto, o que é visto com humor e sagacidade), que não foi submetida à censura. Foram confrontadas as duas realidades demonstradas, tendo como objetivo principal relativizar os universos e iniciar uma discussão dos conteúdos que, por mais inocentes que pareçam, podem revelar a existência de um emissor, um receptor (que é o público que a propaganda quer atingir - o seu público alvo) e uma mensagem. 
Mostramos ainda propagandas governamentais para mostrar como nelas é claro quem fez, para quem foi feito e qual é a mensagem, pois não são propagandas para vender, mas para convencer a ter algum tipo de atitude considerada ideal para os cidadãos. Discutimos com as crianças se elas acham que funciona.

Mostramos uma propaganda governamental da Austrália, que discute a questão de dar bom exemplo às crianças (a propaganda Children See, Children Do). Mostramos também uma propaganda governamental sobre o uso de cocaína e maconha, e discutimos nestas propagandas as formas de passar as sensações desejadas (trilha sonora, planos utilizados, cortes, caracterização do personagem, estrutura narrativa).

Em relação ao vídeo Children See, Children Do, todas as crianças demonstraram empatia com o método utilizado, pois acreditam que a propaganda passa a mensagem sem chocar o telespectador, diferentemente do vídeo sobre o uso da cocaína, que se utiliza de imagens chocantes de um cérebro sendo aberto, como simbologia dos estragos causados pela droga à saúde dos usuários.. As crianças demonstraram entender o conceito, mas acharam a propaganda desagradável, e com isso discutimos que o objetivo da propaganda foi atingido: relacionar a imagem do uso de drogas com uma sensação angustiante. As figuras 2 e 3 mostram imagens dessas propagandas. 


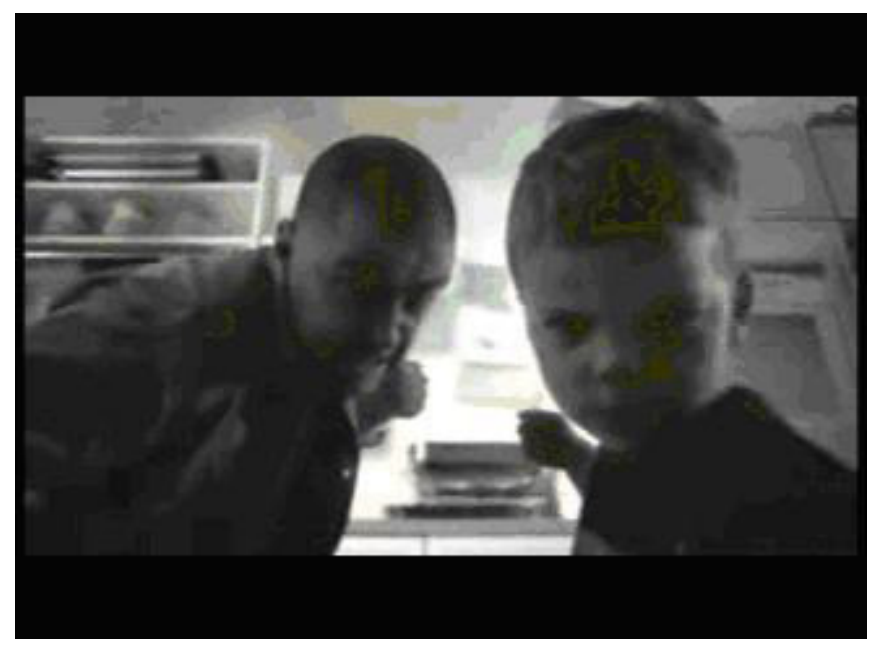

Fig. 2 - Imagem da propaganda Children See, Children Do

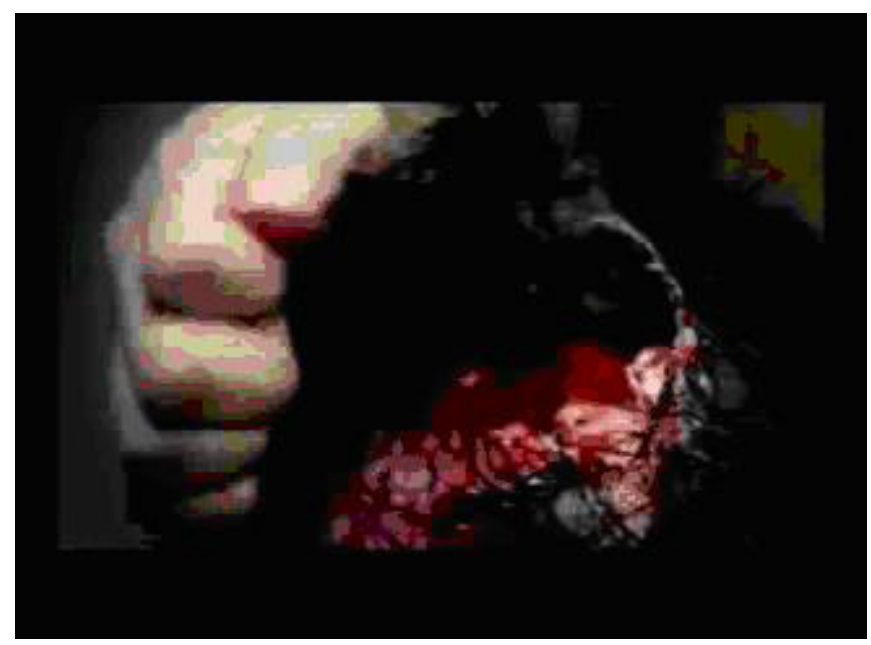

Fig. 3 - Imagem da propaganda governamental contra o uso de cocaína

Para desenvolvermos uma noção mais apurada da análise das propagandas, tratamos um pouco dos mecanismos utilizados por elas ao longo da história. Assim, passamos pelas primeiras propagandas veiculadas na televisão e nas revistas brasileiras, que focavam em descrever todas as propriedades dos produtos (mostramos propagandas antigas do Toddy e da Coca Cola). Os narradores citavam a fórmula dos produtos, e nas revistas, não raro apresentavam-se textos explicativos relativamente extensos. 
Quando as propagandas passaram a ficar mais "enxutas" neste sentido, passaram a focar em um aspecto chave, que seria o chamariz para o consumidor: o preço barato (mostramos uma propaganda das Casas Bahia), o estilo de quem usa o produto, e assim por diante. Mostramos propagandas recentes da Sprite, Sony Ericsson e Mastercard, onde o objetivo é ligar a imagem do produto a um estilo de vida que seja atraente ao consumidor.

Para uma análise mais didática, apresentamos aos alunos os onze temas de propagandas associados aos recursos de convencimento mais usados hoje em dia, que se baseiam nas seguintes palavras-chave: humor, macho, amigos, família, diversão, natureza, sensual, cartoon, celebridade, glamour e prosperidade (Jolls, Share \& Thoman, 2001). Como atividade para as crianças, pedimos que elas fizessem uma propaganda sobre algo, em grupos, para depois filmarmos. Depois assistimos as propagandas que elas fizeram e analisamos os mecanismos que cada grupo escolheu.

Assim, os alunos se dividiram em três grupos e, por iniciativa própria, escolheram diferentes métodos de persuasão. O primeiro grupo utilizou uma cena de humor para vender o produto. O segundo se inspirou nos canais de propaganda, em que a narrativa é simples e focada nas características do produto e seu preço acessível, enquanto o último relacionou cada produto com um estilo de vida pretendido pelo cliente. As figuras 4, 5 e 6 mostram cenas dessas propagandas. 


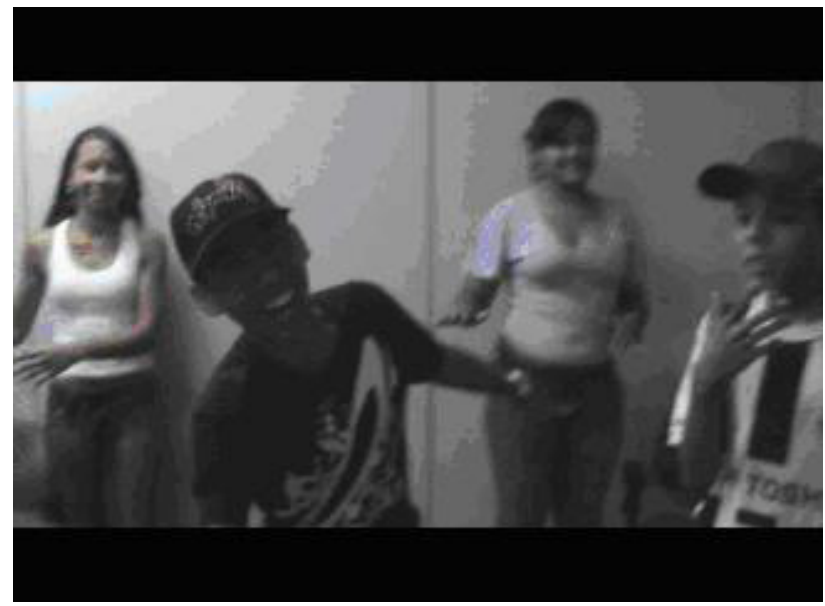

Fig. 4 - Imagem da propaganda "Coisa Coisada: Gostoso de Morrer" (Grupo 1)

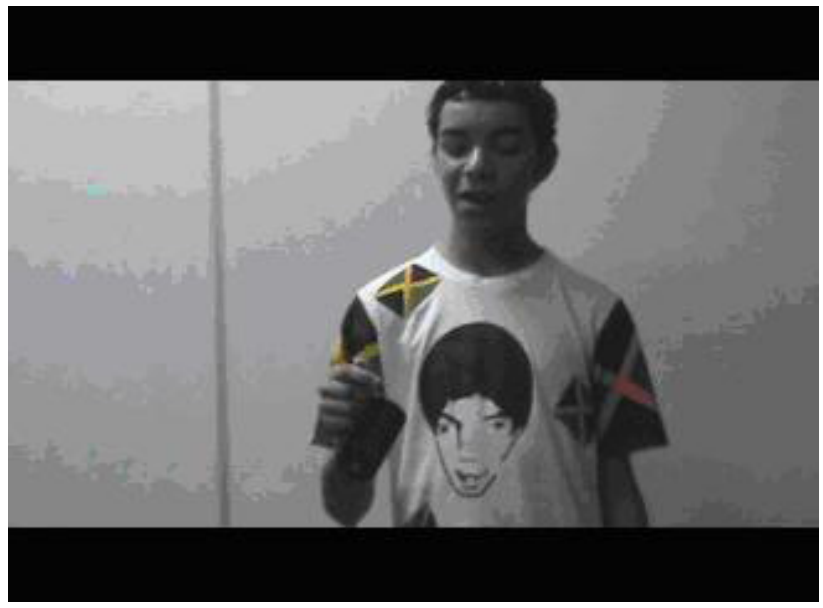

Fig. 5 - Imagem da propaganda "Compre já! Frete grátis!" (Grupo 2)

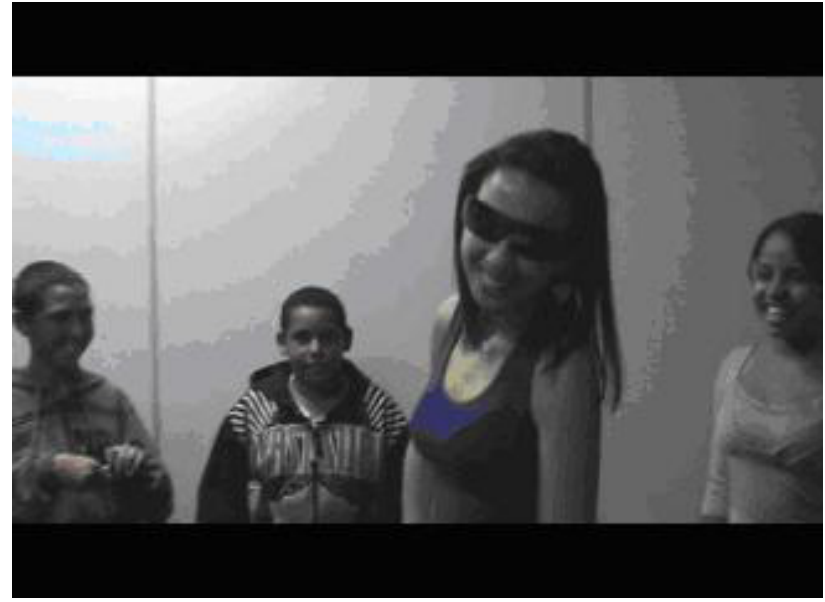

Fig. 6 - Imagem da propaganda: "Os óculos certos para você estão aqui!" (Grupo 3) 
Também pedimos para elas trazerem recortes de propagandas de jornais e revistas para analisarmos em aula, que discutimos e separamos em grupos de acordo com a palavra-chave.

\section{O cinema}

\section{Desmistificando o cinema}

Apresentamos às crianças o making of de filmes de grande circulação no Brasil: Avatar e Harry Potter. O objetivo é desmistificar a produção dos filmes, mostrando que quem os faz são pessoas normais, que têm suas opiniões e que elas podem ser postas em discussão. A compreensão de como se faz um filme o traz mais próximo das crianças, por isso incluímos essa aula sobre as "profissões do cinema".

\section{A estrutura narrativa}

Começamos mostrando às crianças a versão clássica do filme Branca de Neve e os Sete Anões para mostrar como as narrativas na maioria das vezes são baseadas na ocorrência de um conflito que deve ser solucionado pelo personagem principal.

A partir dai, apresentamos a divisão clássica em três atos, mostrando que o primeiro ato é quando aparece a apresentação dos personagens principais, com a apresentação da situação geral e ambientação, quando fica estabelecido o objetivo e aparecem indícios dos obstáculos; e que no segundo ato ocorre a progressão para um ponto culminante de conflito, com as dificuldades sendo elaboradas, o personagem se modificando e subenredos sendo desenvolvidos; o terceiro ato é quando ocorre a solução dos conflitos e problemas - aparecem mudanças e o conflito acaba.

Essa estrutura teórica foi apresentada aos alunos mostrando exemplos de vídeos das mais diversas origens, conforme nosso outro objetivo: a expansão 
do repertório visual das crianças. Posteriormente, mostramos a quebra dessa estrutura em alguns vídeos contemporâneos, já que essa estrutura existe apenas num ideal clássico, que os vídeos modernos tendem a quebrar.

Assim, apresentamos o primeiro ato do curta Alma, de Rodrigo Blaas, e perguntamos às crianças o que elas já sabem da história após esse ato, e o que elas acham que vai acontecer. Depois passamos o vídeo inteiro e pedimos para que elas dissessem como se dá essa divisão em três atos nesse vídeo. Para cristalizar esse conhecimento, mostramos o vídeo Partly Cloudy, da Pixar. Depois, trabalhamos vídeos que desconstroem essa estrutura, como Busby, de Anna Henckel, que faz uma vídeo-arte com imagens de mãos (o que descaracteriza a divisão em três atos) e Tin Toy, da Pixar, em que o personagem muda de objetivo no final do curta, ao invés de realizar seu objetivo inicial.

\section{Os personagens}

Estudamos com as crianças, através do uso de exemplos em vídeos diversos, a divisão de papéis na estrutura clássica de personagens, os arquétipos, bem como a quebra desta expectativa em vídeos mais recentes. Os arquétipos foram apresentados da seguinte maneira:

- Herói: O que se presta ao sacrifício, tem poucos defeitos que o tornam humano, sofre transformações durante a trama e busca o triunfo sobre as adversidades.

- Mentor: Alguém que guia o herói até ele caminhar com os próprios pés, estimula o herói na sua aventura.

- Guardião do limiar: Não precisa necessariamente ser um personagem, mas algo que limita o herói, o desafia antes do grande desafio final, que apresenta o vilão ou conflito.

- Arauto: A gota d'água que vai fazer o herói se motivar a lutar, e encontrar o primeiro guardião do limiar. 
- Camaleão: Um personagem ou situação que não são previsíveis, e causa dúvidas no herói.

- Sombra: Aquilo que antagoniza o herói, pode ser um vilão ou uma fraqueza do herói.

- Pícaro: Aquele que traz comicidade e análise irônica das situações. Causa um alívio na tensão da história, mas também desnuda as questões tratadas.

- Anjo: Aquele que ajuda o herói a voltar para seu caminho, quando ele se desvia dele. O personagem pode não saber que está desempenhando esse papel.

- O orelha: Aquele que faz o personagem falar, e deixar o espectador saber o que ele pensa.

Para tratarmos deste assunto, utilizamos vídeos que apresentassem grande diversidade de personagens, sendo estes desconhecidos pelas crianças: Os Irmãos Williams, de Ricardo Dantas, e Au Bout Du Monde, de Konstantin Bronzit. Primeiramente, apresentamos apenas o áudio das vozes dos personagens e perguntamos aos alunos o que eles podem inferir sobre eles. Com esse exercício, além de iniciarmos a análise dos diálogos, ainda incitamos o olhar sobre os personagens separadamente.

Depois, utilizamos frames congelados das imagens dos personagens e perguntamos às crianças como elas acham que eles são: bravos, calmos, alegres, raivosos, amigos, malvados etc. A imagem do personagem diz muito sobre ele, e essa leitura é interessante no tocante à sua análise.

Somente após estes dois exercícios é que passamos os vídeos completos para que os alunos verifiquem suas respostas e discutam o assunto em grupo, debatendo com eles aquilo que só conseguiram saber dos personagens depois de assistir ao filme. 
Para a análise de personagens passamos também outros filmes, como Gagarin, da Secong Frog Animation Group, e trechos de filmes que apresentam personagens desconhecidos, como: Luxo jr., For the Birds, Mater and the Light (curtas da Pixar).

\section{A trilha sonora}

A música, o som ambiente, os diálogos são elementos chave no desenvolvimento da mensagem do audiovisual atualmente, e trabalham em conjunto com a imagem. Para trazermos uma ideia do quanto sua presença é fundamental nos vídeos de hoje, apresentamos uma breve história do cinema, em que, inicialmente, não contávamos com a maioria dos elementos de áudio.

Por isso, primeiramente, executamos com os alunos um exercício: pedimos a eles que desenvolvam e executem uma história de ação, sem poder contar com o áudio. Assim, eles podem perceber que a linguagem inteira muda quando não podemos contar com o som, uma vez que o que seria dito com um elemento deve ser totalmente abrangido pelo outro.

A trilha sonora acrescenta informações sobre a narrativa do audiovisual. Utilizando o vídeo Le Moine et le Poisson, de Michael Dudok de Wit, trabalhamos o áudio como detentor de informações extremamente relevantes sobre a trama: a hora do dia, o local em que se dá a história, o humor dos personagens. A música informa tudo, pois os personagens não falam.

A música é muitas vezes uma tradução do sentimento dos personagens. No filme The Kid, de Charles Chaplin, as emoções se traduzem magistralmente na música clássica utilizada. Passamos um trecho desse filme, primeiro sem o áudio, e depois com ele, e analisamos as diferentes percepções que as crianças apresentam.

Para exemplificarmos os diferentes usos criativos da música nos filmes, usamos como exemplo cenas do filme Kill Bill, em que o uso da trilha sonora nas 
cenas de luta é bastante criativo, fugindo à norma clássica e suscitando novas sensações ao expectador, em relação à trilha de filmes clássicos de luta como no filme O Reino Proibido, com Jet Li e Jackie Chan. Para isso, primeiro passamos trechos desses filmes sem o som e depois passamos com áudio e vídeo para que eles analisassem a diferença.

Trabalhando as diferentes sensações que a música pode trazer ao vídeo, fizemos um exercício com as crianças, que consiste em utilizar diferentes estilos de música na trilha sonora de um mesmo vídeo. Assim, passamos cenas de um programa sobre a vida dos leões com os estilos de música reggae, jazz e música clássica, e comentamos as diferentes sensações suscitadas.

\section{A montagem}

O objetivo do curso não é ensinar os pormenores da montagem fílmica, mas atentar a detalhes que podem melhorar a apreensão da mensagem de cada vídeo. Assim, introduzimos a ideia de montagem utilizando um trecho da animação Up, da Pixar: a sequência ao som de Married Life, tema composto por Michael Giacchino. Na sequência, em dois minutos é mostrada toda a vida do casamento dos dois personagens. Quando questionadas sobre quanto tempo tem aquele vídeo, as crianças tenderam a duas respostas: 2 minutos ou 50 anos. Isto se dá porque, graças à montagem, um vídeo de 2 minutos de duração tem a capacidade de ilustrar 50 anos de vida do personagem principal.

Essa sequência foi mostrada várias vezes à medida que discutimos os vários aspectos da montagem, explicando os termos mais utilizados, tais como:

- Montagem: organização dos planos do filme em certas condições de ordem e de duração.

- Plano: O "pedaço de filme" entre duas ligações, dois cortes. Um plano pede por outro, e sua sequência resulta no filme.

- Cena: unidade de lugar e tempo. 
Nesse momento, os alunos já estão preparados para noções de cortes e suas consequências na percepção do público sobre os personagens. Utilizamos o vídeo Lifted, da Pixar, para explicar tipos de posições de câmera e tipos de plano, conceitos como plongée (visto de cima), contra plongeé (visto de baixo), campo e contra campo (posições opostas), plano de conjunto (grupo de personagens), plano médio (pessoa da cintura para cima), primeiro plano (mais perto da câmera), e suas principais utilizações.

Para discutir edição, passamos o making of do filme Harry Potter. Depois passamos o filme Le Moine et le Poisson (que eles já haviam assistido antes) e o filme Kill Bill inteiro para que eles observassem os planos e dessem exemplos de tipos de plano e posições de câmera, e discutimos alguns dos principais objetivos da montagem, como: mostrar o que o personagem vê de fato e o que ele pensa, o que está fora da visão do personagem, entre outros.

\section{Os símbolos, metáforas e elipses}

Dentro da linguagem cinematográfica, é importante analisarmos as mensagens dadas como símbolos ou metáforas, pois são meios importantes de se criar um contexto que pode ser comparado à realidade do receptor.

Para discutirmos esses recursos de significação, utilizamos trechos dos filmes Wallace e Gromit - a batalha dos vegetais e Shrek, ambos da Dreamworks.

As metáforas foram vistas como relações estabelecidas entre duas imagens do vídeo, que são possibilitadas pelo corte e que permitem inferências, como por exemplo: o corte do rosto de um policial raivoso com um cavalo bravo; e a comparação dos trabalhadores entrando com um rebanho de ovelhas.

Os símbolos foram mostrados através de imagens que têm em si a significação que querem passar. Como por exemplo: 
- Personagem diante do cenário: um flash fotográfico que parece uma auréola.

- Duas ações simultâneas: um funeral ao fundo de um casamento.

- Sonoro combinado com visual: o ranger de uma carroça exprime a dor de uma pessoa.

- Inscrição: placas, anúncios, bilhetes que ajudam a entender algum elemento da cena.

As elipses foram mostradas nos filmes através de informações ou imagens que são propositadamente ocultadas do espectador, como um recurso dramático. Como por exemplo:

- Omissão da cena mais importante pode dar um suspense grande para a cena. Exemplo: um soldado ergue a espada - corta para o outro que cai no chão.

- Elipses de estrutura: o espectador não tem uma informação importante que o move a assistir o filme. Exemplo: não sabemos quem é o assassino.

- Elipse de suspense: o espectador fica um tempo sem saber quem ganhou ou quem perdeu a luta.

- Elipse sonora: vê-se a imagem da pessoa falando, mas não o som do que ela diz.

- Elipse simbólica: ao invés de mostrar a briga dos personagens, mostra uma panela de pressão, ao invés de mostrar um casal namorando, mostra uma onda no mar etc.

Ainda trabalhando com a significação, passamos os vídeos Ilha das Flores, de Jorge Furtado e Man in the Frame, de Fyodor Khitruk, ambos na íntegra, e pedimos às crianças para exemplificarem os recursos simbólicos 
e sua contribuição para a apreensão do enredo, e suas consequentes relações com o cotidiano.

\section{Os diálogos}

Os diálogos são não só um dos fatores que influenciam a narrativa, mas também fortalecem a individualidade de cada personagem, sendo um elemento importante na sua caracterização.

Para despertar a atenção para os diálogos, passamos o trailer do filme Toy Story 3, primeiro só o áudio, perguntando quantas vozes diferentes eles podem perceber, e, depois de identificarem as vozes, como eles acham que são esses personagens. Depois disso, passamos o vídeo junto com o áudio para eles verem os personagens que imaginaram e comparar com a impressão que tiveram de suas vozes.

Para envolver as crianças na criação de diálogos, foi realizada uma atividade com quadrinhos: A partir de fragmentos de quadrinhos, as crianças, organizadas em grupos, tiveram que colocar os quadrinhos em ordem, de acordo com a aula de montagem, e escreveram os diálogos nos balões de fala que estavam em branco, reinventando a história e caracterizando os personagens através do diálogo. Ao final foi discutido o trabalho dos grupos. A figura 7 ilustra essa atividade. 


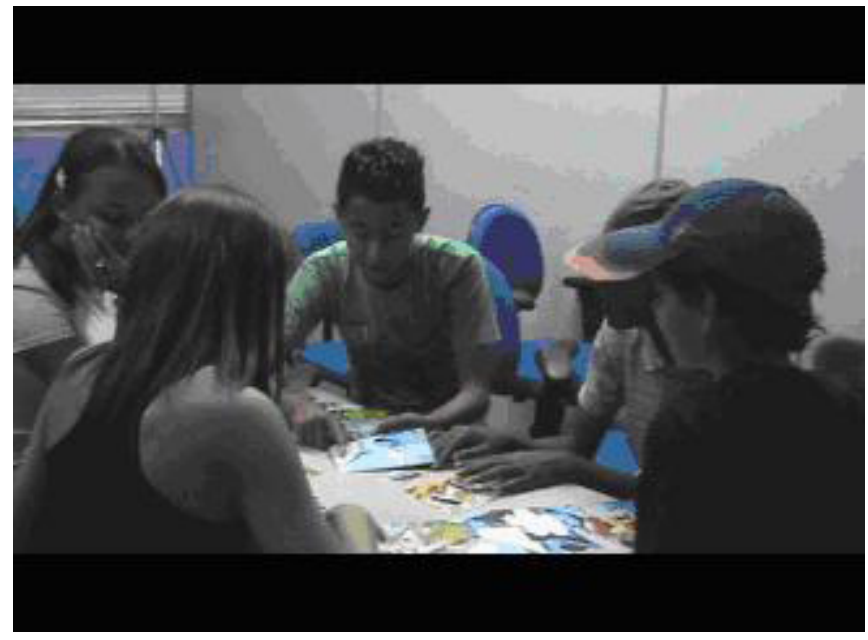

(7a)

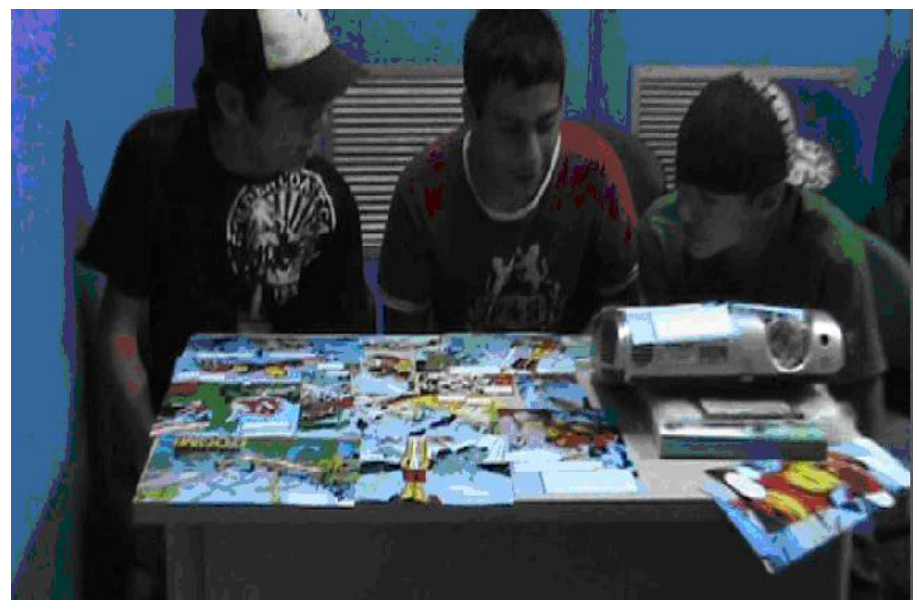

(7b)

Fig. 7 - Alunos realizando exercício com quadrinhos 


\section{Considerações finais}

Durante a oficina realizada em Caxiuanã (PA), as crianças tiveram oportunidade de analisar e discutir os filmes que foram apresentados, através dos exercícios que realizaram. O trabalho final da oficina envolveu a criação de histórias em quadrinhos pelos grupos, a partir de fragmentos incompletos de quadrinhos que os grupos utilizaram para compor uma história explorando vários conceitos vistos na oficina, como por exemplo, o de estrutura narrativa e o de uso do diálogo para criação da identidade dos personagens. Ao final da Olimpíada, cada grupo apresentou a sua história em quadrinhos em plenária, para todos os participantes da Olimpíada. Em algumas apresentações, as crianças, por sua própria iniciativa, organizaramse para que cada criança do grupo interpretasse os diálogos dos personagens da história em quadrinhos que criaram.

O grupo de crianças do curso de Campinas (SP) foi bastante participativo, mais ativo do que o grupo de Caxiuanã. Consideramos esta diferença natural, já que as crianças de Campinas detêm um repertório audiovisual mais diverso em relação ao primeiro grupo, sendo que já possuem muitas das linguagens audiovisuais intuitivamente em sua experiência de vida.

$\mathrm{Na}$ continuidade do trabalho, o curso deve ser aplicado em outros contextos sócio-econômicos e regionais, diferentes dos grupos utilizados anteriormente, para que possamos ter uma visão mais clara das especificidades, necessidades e tendências do público brasileiro no aprendizado da linguagem das mídias audiovisuais.

Em outro projeto em desenvolvimento, iremos explorar a criação de um curso de Alfabetização em Mídias para ser veiculado através da TV digital interativa. Nesse projeto, pretendemos atrelar ao curso a discussão de materiais de jornalismo, tais como jornais televisivos, de rádio, de revista e na web, e atrelar a discussão de conteúdo de vídeos com temas como diversidade e cidadania. 


\section{Referências}

BORTOLETTO, M. Ideologias animadas: a criança e o desenho animado. Campinas: Editora da Unicamp, 2008.

CAMPOS, F. Roteiro de cinema e televisão. Rio de Janeiro: Zahar, 2007.

HOWARD, D \& MABLEY, E. Teoria e prática do roteiro. São Paulo: Globo, 2005.

JOLLS, T.; SHARE, J. \& THOMAN, E. Five key questions that can change the world: lesson plans for Media Literacy. Nova Iorque: CML, 2001.

JOLLS, T. \& THOMAN, E. Literacy for the $21^{\text {st }}$ century: an overview and orientation guide to Media Literacy Education. Nova Iorque: CML, 2007.

MARTIN, M. \& GRANJA, V. A linguagem cinematográfica. São Paulo: Brasiliense, 2007.

MATTELART, M. História das teorias da comunicação. São Paulo: Loyola, 2004.

PEIRCE, C. S. Semiótica. São Paulo: Perspectiva, 2003.

SANTOS, L. C. \& Akhras, F. "An audiovisual media literacy approach to promote social inclusion". Paper accepted for oral presentation at the Media Literacy Conference (Londres/Inglaterra, 2010).

WILIAM, D. Moving images in the classroom: a secondary teachers' guide to using film and television. London: BFI, 2000.

\section{Filmografia}

ALMA (2009). Diretor: Rodrigo Blaas. Produção: Rodrigo Blaas. Espanha. Duração: 5 minutos 30 segundos.

A MULHER INVISÍVEL (2009). Warner Bros. Diretor: Cláudio Torres. Roteiro: Cláudio Torres. Elenco: Selton Melo, Luana Piovani. Duração: 105 minutos.

AVATAR (2010). Fox Films. Diretor: James Cameron. Roteiro: James Cameron. Elenco: Giovanni Ribisi, Michelle Rodriguez. Duração: 166 minutos. 
BUSBY (1997). Direção: Anna Henckel. Produção: Filmakademie Baden-Württemberg. Alemanha. Duração: 3 minutos 18 segundos.

CHELOVEK V RAMKE (THE MAN IN THE FRAME) (1966). Direção: Fiodor Khitruk. Produção: Fiodor Khitruk. Rússia. Duração: 10 minutos.

GAGARIN (1993). Direção: Alexey Kharitidy. Produção: Alexey Kharitidy. Rússia. Duração: 3 minutos 35 segundos.

HARRY POTTER AND THE HALF BLOOD PRINCE (2009). Warner Home Video. Diretor: David Yates. Roteiro: J. K. Rowling. Elenco: Rupert Grint, Emma Watson, Daniel Radcliffe. Duração: 140 minutos.

ILHA DAS FLORES (1989). Direção: Jorge Furtado. Produção: Mônica Schmiedt, Giba Assis Brasil, Nôra Gulart. Brasil. Duração: 13 minutos.

KILL BILL VOL. 1 (2003). Miramax. Direção: Quentin Tarantino. Roteiro: Quentin Tarantino.Elenco: Uma Thurman , Lucy Liu. Duração: 110 minutos.

KILL BILL VOL. 2 (2004). Miramax. Direção: Quentin Tarantino. Roteiro: Quentin Tarantino. Elenco: Uma Turman, David Carradine. Duração: 134 minutos.

LE MOINE ET LE POISSON (1994). Direção: Michael Dudok de Wit. Produção: Folimage. França. Duração: 6 minutos.

NEIGHBOURS (1952). Diretor: Norman Maclaren. Roteiro: Norman Maclaren. Canada. Duração: 8 minutos 5 segundos.

PIXAR SHORT FILMS COLLECTION (2007). Pixar. Duração: 55 minutos.

SHREK (2001). Dreamworks. Direção: Andrew Adamson, Vicky Jenson. Roteiro: Ted Elliott, Terry Rossio, Joe Stillman e Roger S. H. Schulman, baseado em livro de William Steig. Duração: 93 minutos.

SNOW WHITE AND THE SEVEN DWARFS (1937). Disney. Direção: David Hand. Roteiro: Dorothy Ann Blank, Richard Creedon, Merrill De Maris, Otto Englander, Earl Hurd, Dick Rickard, Ted Sears e Webb Smith, baseado em estória de Jacob Ludwig Carl Grimm e Wilhelm Carl Grimm. Duração: 83 minutos

THE CURSE OF THE WERE-RABBIT STARRING WALLACE \& GROMIT (2005). Dreamworks. Direção: Steve Box, Nick Park. Roteiro: Bob Baker, Steve Box, Nick Park, Mark Burton. Duração: 94 minutos. 
HE FORBIDDEN KINGDOM (2008). The Weinstein Company. Direção: Rob Minkoff. Roteiro: John Fusco. Duração: 113 minutos.

THE KID (1918). Cinemax. Diretor: Charles Chaplin. Roteiro: Charles Chaplin. Elenco: Charles Chaplin, Edna Purviance. Duração: 107 minutos.

TOY STORY 3 (2010). Pixar. Direção: Lee Unkrich. Roteiro: Michael Arndt. Duração: 113 minutos.

UP (2009). Pixar. Direção: Pete Docter e Bob Peterson. Roteiro: Bob Peterson e Pete Docter. Duração: 96 minutos.

\section{Videografia}

ANTI DRUG COMMERCIAL. Disponível em: http://www.youtube.com/watch?v=pVRO_ a6pQB8\&p=5276E97D16E2ADF7\&playnext=1\&index=51. Acesso em: 25/11/2009.

CAMPANHA "DROGAS NEM MORTO" - MACONHA. Disponível em: http://www.youtube. com/watch?v=cuf8wohv6TQ. Acesso em: 23/10/2009.

CAMPANHA "NÃO TEM PREÇO" MASTERCARD. Disponível em: http://www.youtube.com/ watch?v=hWZYFrjsGvo. Acesso em: 23/10/2009.

CHILDREN SEE, CHILDREN DO. Disponível em: http://www.youtube.com/ watch?v=KHi2dxSf9hw. Acesso em: 26/11/2009.

CHINESE SPRITE COMMERCIAL. Disponível em: http://www.youtube.com/ watch?v=TssBhZI9Bp8. Acesso em: 24/10/2009.

COMERCIAL ANTARTICA COM JULIANA PAES. Disponível em: http://www.youtube.com/ watch?v=AH0-4iOfwa0\&p=2043EA258FC1BEC6\&playnext $=1 \&$ index $=17$. Acesso em: $21 / 10 / 2009$.

COMERCIAL CASAS BAHIA. Disponível em: http://www.youtube.com/ watch?v=hGbXaQr8tr4. Acesso em: 23/10/2009.

COMERCIAL SONY ERICSSON W580. Disponível em: http://www.youtube.com/ watch?v=3t7WIRNWH1s. Acesso em: 22/10/2009.

HAVAIANAS FIT - NA ÍNTEGRA (COMERCIAL CENSURADO). Disponível em: http://www. 
youtube.com/watch?v=y1qSCpDEgXA. Acesso em: 20/10/2009.

MERCHANDISING TUCSON. Disponível em: http://www.youtube.com/watch?v=BSRuhVo_Bg. Acesso em: 15/10/2009.

PATO DONALD "O MELHOR DO PATO DONALD". Disponível em: http://www.youtube. com/watch?v=cWSvhI4k7F4. Acesso em: 01/10/2009.

PRIMEIRA CAMPANHA PUBLICITÁRIA DE TODDY (1958). Disponível em: http://www. youtube.com/watch?v=IhpJAwl2fEY. Acesso em: 23/10/2009.

PROPAGANDA ANTIGA DA COCA COLA (VÁRIAS PROPAGANDAS ANTIGAS). Disponível em: http://www.youtube.com/watch?v=DwADsAZmGk0\&feature=related. Acesso em: 23/10/2009.

1 O trabalho apresentado neste artigo teve apoio financeiro do Conselho Nacional de Desenvolvimento Científico e Tecnológico (CNPq). Agradecemos à coordenação da II Olimpíada de Ciências na Floresta, do Museu Paraense Emílio Goeldi, pela oportunidade de realizarmos uma oficina de Alfabetização em Mídias na Floresta Nacional de Caxiuanã (PA).

2 Graduanda do bacharelado em Midialogia do Instituto de Artes da Universidade Estadual de Campinas (Unicamp). Email: lilian.chaplin@gmail.com.

3 Doutor em Educação pela Universidade de Leeds (Inglaterra), é professor do Programa de Pós-Graduação em Multimeios da Universidade Estadual de Campinas (Unicamp) e coordenador do Grupo de Tecnologias de Mídia para a Inclusão Social do Centro de Tecnologia da Informação Renato Archer (CTI). Email: fabio. akhras@cti.gov.br. 